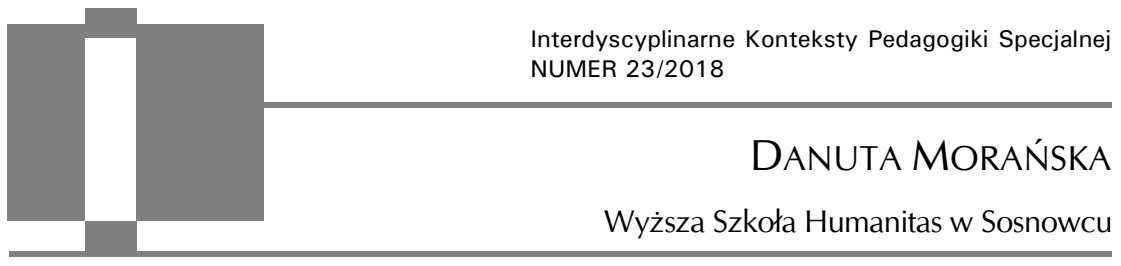

\title{
Nowa jakość kształcenia akademickiego w sytuacji zmiany cywilizacyjnej - interaktywny wykład problemowy
}

\begin{abstract}
Danuta Morańska, Nowa jakość kształcenia akademickiego w sytuacji zmiany cywilizacyjnej - interaktywny wykład problemowy [The new quality of academic education in the face of a civilisation change - the interactive problem-focused lecture]. Interdyscyplinarne Konteksty Pedagogiki Specjalnej, nr 23, Poznań 2018. Pp. 221-234. Adam Mickiewicz University Press. ISSN 2300-391X. DOI: https://doi.org/10. 14746/ikps.2018.23.13

The article presents important problems that colleges and universities will have to face in order to adapt its didactic offer to the requirements of the present day. The article is based on the research conducted by the author during the training of the researchers and teachers at one of the Polish technical universities.
\end{abstract}

KEY WORDS: education, modern academic didactics

\section{Wprowadzenie}

Rozwój technik informatycznych permanentnie zmienia codzienne życie współczesnego człowieka. Systematycznej zmianie ulega charakter dotychczasowych wytworów posiadających konotacje humanistyczne czy też społeczne. Tradycyjny list został zastąpiony e-mailem, książka e-bookiem i audiobookiem. Dotychczasowe 
biblioteki zamieniły się $\mathrm{w}$ biblioteki cyfrowe. Pojawiła się Wikipedia, e-czasopisma, a pamiętniki i albumy zostały zastąpione przez fotoblogi, vlogi, blogi itp. W powszechny użytek weszły nowe formy i modele komunikacji, $\mathrm{w}$ tym fora dyskusyjne, serwisy i media społecznościowe. Powstały elektroniczne zasoby informacji $\mathrm{w}$ postaci baz danych, repozytoriów. Zastosowanie internetu zmieniło lub poszerzyło zakres funkcji dotychczasowych produktów i sposobów ich użytkowania. Wiele działań realizowanych w tradycyjny sposób, po zmodyfikowaniu, znalazło swój odpowiednik w cyberświecie. Niezwykle ważnym atutem współczesności stał się nie tylko szybki i powszechny dostęp do informacji (Web 1.0), ale również możliwości ich wymiany oraz współtworzenia (Web 2.0). Sytuacja ta dla współczesnych pokoleń, zanurzonych w cyfrowym świecie, wydaje się oczywista i naturalna.

Przystępny, natychmiastowy dostęp do informacji zamieszczonych w sieci, możliwość ich personalizacji i wymiany, przyspieszył znacznie proces podejmowania decyzji, wpłynął również na szybkość i zwiększył samodzielność rozwiązywania problemów z różnych dziedzin. Można sformułować tezę, że dzięki swobodzie dostępu do zasobów i usług sieciowych, poszerzających zestaw narzędzi i pole poznawcze człowieka, współczesny człowiek stał się bardziej samodzielny, wyemancypowany. Uzyskując dostęp do repozytoriów, może z nich korzystać, jednocześnie dzięki dostępnym mechanizmom może stać się ich współtwórcą. Ze względu na dynamicznie zmieniające się środowisko życia, w którym pojawiają się coraz nowsze możliwości działania $\mathrm{z}$ zastosowaniem metod i cybernarzędzi, współczesny człowiek musi włożyć wiele wysiłku w poznanie i dostosowanie się do nowej rzeczywistości, jednocześnie kreatywnie i twórczo zaimplementować ją do codziennego funkcjonowania. Takie warunki stawia nowa cywilizacja cyfrowa. Tym bardziej, że cechy współczesnych pokoleń, ich aktywność, sprawność w działaniu oraz umiejętność szybkiej adaptacji do nowych warunków i kreatywność sprzyjają rozwijaniu kompetencji kluczowych w procesie edukacji całożyciowej. 


\section{Kogo uczymy?}

Roman Friedrich, Michael Peterson ${ }^{1}$ określili współczesne młode pokolenie jako pokolenie. Dokonując charakterystyki, zastosowali trzy przymiotniki: connect, communicate, change - ang. podtaczeni, skomunikowani, dostosowujący się do zmian. O przynależności do tej społeczności nie zawsze decyduje wiek, ale otwartość na zmianę i szybkość włączenia się do nowej, cyfrowej rzeczywistości, nabycie cech digital natives. Najprawdopodobniej decyduje moment, w którym internet i social media stały się nieodłączną częścią życia danego pokolenia².

Cechą charakterystyczną pokolenia $C$ jest ciągle doświadczanie i w ten sposób zdobywanie wiedzy o świecie. Mając dostęp do wielu źródeł informacji, młodzi ludzie synkretycznie konstruują swoją wiedzę. Budują własną tożsamość, poszukują równowagi dającej poczucie stabilności, bezpieczeństwa $\mathrm{w}$ sytuacji permanentnego rozwoju. Takie podejście do informacji stanowi wartość polegającą na otwarciu się zmianę, nowe rozwiązania. Właściwie nie jest to cecha wyróżniająca. Stanowi ona właściwość charakteryzującą każde młode pokolenie. Zmieniły się tylko metody i narzędzia, którymi posługują się współcześni młodzi ludzie. Pokolenie C charakteryzuje większe poczucie niezależności, samodzielności niż poprzednie społeczeństwa. Dzięki ciągłej aktywności w internecie, w sposób naturalny wykształciło poczucie autonomii, sprawstwa, kontroli nad własnym działaniem, $\mathrm{w}$ tym uczeniem się. Takie atrybuty jak szybkość wymiany informacji i podejmowania decyzji, działanie wielowątkowe i zaradność stanowią pochodną aktywności w sieci. Badania potwierdzają, że aktywność poznawcza współczesnego człowieka w połączeniu z łatwością dostępu do źródeł informacji, wpływa na znaczne zwiększenie szybkości procesu uczenia się,

${ }^{1}$ R. Friedrich, M. Peterson, A. Koster, S. Blum, The Rise of Generation C. Implications for the World of 2020, Booz \& Company, 2010, s. 2, http://www.itdl.org/jour nal/jan_05/article01.htm [dostęp: 15.07.2018].

2 J. Morbitzer, O istocie medialności młodego pokolenia, "Neodidagmata” 2012, nr 33/34, 2011/2012, s. 136-139. 
w tym rozwiązywanie złożonych problemów. Kwestią naczelną jest zatem wystąpienie sytuacji problemowej, wymagającej wysiłku intelektualnego i rozwiązywanie jej przy zastosowaniu ogólnie dostępnych metod, narzędzi i środków, w tym współczesnych metod i narzędzi cyfrowych. Stymulowanie ciekawości poznawczej, przy uwzględnieniu specyficznych strategii działania młodych ludzi zanurzonych w wirtualnym świecie, stwarza możliwości do osiągania wysokich efektów kształcenia.

Ciągła aktywność i samodzielność w sytuacji ciągle zmieniającej się rzeczywistości, zmienia oczekiwania młodzieży względem metod kształcenia stosowanych w szkołach, również wyższych. Oczekują zmiany, dostosowania procesu kształcenia do współcześnie stosowanych strategii konstruowania wiedzy. Tradycyjne modele uczenia się wydają się im anachroniczne, niedostosowane do współczesności, szczególnie gdy polegają na transmisji wiedzy, która znajduje się w innych, ogólnodostępnych repozytoriach. Nie chcą zdobywać wiedzy wyłącznie na poziomie zapamiętania. Demotywująca jest niska ocena przydatności sposobu transmisji wiedzy. Jednocześnie w codziennym funkcjonowaniu studenci mają do dyspozycji szybki dostęp do informacji, są aktywni, funkcjonują w społecznościach sieciowych. Komparacja wiedzy z wiedzą innych, mobilność oraz brak ograniczeń czasowych i przestrzennych $\mathrm{w}$ dostępie do informacji, tak dystynktywne dla cyberprzestrzeni, sprzyja budowaniu nowych strategii rozwiązywania problemów, zachęca do współpracy, zwiększa zaangażowanie, motywację do podejmowania różnorodnych aktywności związanych z budowaniem własnej wiedzy. Współcześnie proces poznania ma charakter fenomenologiczny zgodnie zasadami hermeneutyki³.

Oczekuje się zatem, że aby możliwości stwarzane przez nowe środowisko życia były przez człowieka kreatywnie i twórczo wykorzystywane. W procesie edukacji priorytetowo należy traktować te metody i formy kształcenia, które sprzyjają rozwijaniu myślenia problemowego, wykorzystując potencjał uczących się podmiotów.

${ }^{3}$ D. Morańska, Refleksyjne uczenie się w akademickiej edukacji zdalnej, https://re pozytorium.ur.edu.pl/handle/item/2967, 2017 [dostęp: 15.07.2018]. 
Ich zastosowanie powinno sprzyjać wywoływaniu refleksyjności ${ }^{4}$ i odpowiedzialności $w$ procesie konstruowania wiedzy. Na ten problem zwrócili uwagę Benjamin S. Bloom oraz Bolesław Niemierko5, tworząc taksonomię celów kształcenia. Obaj badacze preferują osiąganie $\mathrm{w}$ procesie kształcenia celów najwyższych związanych $\mathrm{z}$ nabywaniem umiejętności operowania wiedzą. Learning by doing Johna Deweya stanowi zatem wyznacznik dla współczesnych organizatorów kształcenia, w tym również nauczycieli akademickich. Zadaniem współczesnych nauczycieli jest kierowanie, zarządzanie procesem budowania przez studentów ich wiedzy i organizowanie dla nich odpowiedniego środowiska uczenia się.

Kontynuacja prac na rozwojem sztucznej inteligencji spowoduje, że tylko jednostki kreatywne, otwarte na zmianę, myślące refleksyjnie i perspektywicznie, twórcze, potrafiące wzajemnie współpracować będą odnosiły sukcesy osobiste i zawodowe. Rozwijanie tych kompetencji uznaje się współcześnie za ważniejsze niż wyposażanie w szczegółową wiedzę merytoryczną, która dynamicznie ulega zmianom.

Kluczem do zaspokojenia potrzeb uczących się i stworzeniem im warunków do aktywnego uczenia się jest poszerzenie kompetencji dydaktycznych nauczycieli o wiedzę dotyczącą zastosowania w dydaktyce akademickiej problemowych metod kształcenia ${ }^{6}$.

\section{Nowe spojrzenie na dydaktykę}

Nowe modele aktywności w świecie stanowiącym synergię realnej i wirtualnej rzeczywistości oraz zmiana narzędzi i metod dzia-

${ }^{4}$ A. Perkowska-Klejman A., Modele refleksyjnego uczenia się, http://terazniejszosc. dsw.edu.pl/fileadmin/user_upload/wydawnictwo/TCE/2013_6-1_5.pdf, 2013 [dostęp: 15.07.2018].

${ }^{5}$ B.S. Bloom, Taxonomy of Educational Objectives Book 1: Cognitive Domain, 2nd edition. Addison Wesley Publishing Company, 1984; B. Niemierko, Ocenianie szkolne bez tajemnic, WSiP, Warszawa 2002, s. 29-51.

${ }^{6}$ D. Morańska, Refleksyjne uczenie się w akademickiej edukacji zdalnej, https://re pozytorium.ur.edu.pl/handle/item/2967, 2017 [dostęp: 15.07.2018]. 
łania współczesnego człowieka stały się istotnym problemem dzisiejszej dydaktyki, szczególnie akademickiej. Wyraźnie można dostrzec, że dotychczas stosowane modele kształcenia akademickiego (np. klasyczny wykład informacyjny) nie przynoszą oczekiwanych efektów.

Współczesne podejście do realizacji procesu kształcenia wymaga uwzględnienia wielu integralnych składowych, które oddziałują na siebie synergicznie. Wśród nich kluczowe znaczenie mają:

- cechy charakteryzujące podmioty uczestniczące w procesie dydaktycznym, w tym ich dotychczasowe doświadczenie, a także wykształcone strategie poznawcze stosowane w codziennym funkcjonowaniu; dzięki temu możliwe jest zrozumienie mechanizmów uczenia się, którymi posługują się współcześni uczący się i adekwatne planowanie sytuacji edukacyjnych, dostosowanych do ich preferencji;

- środowisko, w którym odbywa się kształcenie, jego koherencja ze środowiskiem życia uczących się;

- wysoki poziom aktywności w procesie uczenia się;

- wysoki poziom motywacji do uczenia się.

Jednym z najistotniejszych czynników decydujących o osiąganych efektach kształcenia jest stymulowanie motywacji do uczenia się. Można z całą odpowiedzialnością stwierdzić, że współcześnie w dydaktyce akademickiej nie tylko „co?”, czyli treści kształcenia, ale również "jak?", czyli sposób ich przedstawiania, decyduje o efektywności procesu kształcenia. Natomiast ze strony studentów najczęściej pojawiają się pytania: „po co się tego uczę?”, ,jaki to ma sens?" Uwzględnienie odpowiedzi na wymienione pytania stanowi kluczowy warunek planowania procesu kształcenia i aranżowania przez wykładowcę sytuacji edukacyjnych.

Przyjęcie we współczesnej dydaktyce paradygmatu konstruktywistycznego ${ }^{7}$ wprowadza zasadnicze zmiany $\mathrm{w}$ sposobie postrzegania procesu kształcenia oraz zmienia, w porównaniu $\mathrm{z}$ dotychczasową, definicję ról nauczyciela i studenta. Obowiązuje zatem zasada

7 J.S. Bruner, H. Haste, Making sense. The child's construction of the world, Methuen, New York 1987. 
postrzegania studenta jako aktywnego podmiotu, konstruującego swoją wiedzę $w$ środowisku społecznym, $w$ trakcie realizacji zadań zgodnie z zaplanowaną przez prowadzącego sytuacją edukacyjną. Wyraźnie określa ona rolę nauczyciela jako osoby zarządzającej procesem uczenia się studentów. Przyjęcie zasad organizacji treści kształcenia znacząco wpływa na podniesienie motywacji do uczenia się.

1. Od ogółu do szczegółu - ukazanie poznawanych treści w szerszym kontekście, przy zachowaniu zasad korelacji treści kształcenia.

2. Od praktyki do teorii - wskazanie miejsca zastosowania poznawanej wiedzy uzasadniającej potrzebę jej poznania, $\mathrm{w}$ zgodzie z zasadami procesu badawczego.

Zachowanie zasad korelacji treści kształcenia oraz umieszczanie poznawania wiedzy w szerszym kontekście poznawczym sprzyja budowaniu przez studentów struktur wiedzy i jej organizację. Natomiast wprowadzenie zasady nawiązywania do praktycznego zastosowania wiedzy poprzez prezentacje przykładów jej zastosowania $\mathrm{w}$ sytuacjach związanych $\mathrm{z}$ poznawanym zawodem lub powiązanych ze środowiskiem funkcjonowania studentów wskazuje na jej przydatność, budząc u uczących się potrzebę poznania. Najtrudniejsze zadanie $\mathrm{w}$ tym zakresie przypada nauczycielom przedmiotów o wysokim stopniu abstrakcji, np. matematykom.

\section{Charakterystyka badań}

Opisany model wykładu stanowi propozycję ustaloną na podstawie analiz klasycznego wykładu akademickiego i jego adekwatności do współczesnych wymagań, przeprowadzonych w grupie 28 nauczycieli akademickich, biorących udział w szkoleniach dotyczących doskonalenia kształcenia akademickiego. Badani nauczyciele akademiccy nie są pedagogami. $\mathrm{W}$ badaniach zastosowano metodę indywidualnych przypadków, technikę sędziów kompetentnych. Należy podkreślić wysokie zaangażowanie badanych $\mathrm{w}$ realizacje zadania polegającego na wypracowaniu rozwiązań 
metodycznych możliwych do zaimplementowania w organizowanym przez siebie procesie kształcenia studentów, w celu poprawy jego efektywności.

W trakcie badań poszukiwano sposobów na zwiększenie zaangażowania studentów w proces uczenia się. Zwrócono uwagę na następujące kwestie wymagające poprawy:

- niska frekwencja studentów na wykładach,

- przygotowanie studentów do egzaminów zgodnie z niepisaną regułą studencką: „zakuć, zdać, zapomnieć”,

- słabe zaangażowanie studentów w realizację zadań i projektów,

- negatywne, nieetyczne zachowanie, takie jak odtwórstwo, plagiatowanie, powierzchowność analiz.

Badani uczestniczyli w szkoleniach dotyczących wdrażania nowoczesnych metod do procesu kształcenia w dydaktyce akademickiej. Szkolenie prowadzone było metodą Design Thinking. Przed przystąpieniem do konstruowania propozycji rozwiązań zrealizowano etap empatyzacji, polegający na pogłębionej charakterystyce cech studentów podejmujących naukę na uczelni. Następnie zdefiniowano problemy wymagające rozwiązania.

$\mathrm{W}$ związku z tym, projektując zmiany w procesie kształcenia, wzięto pod uwagę następujące zadania:

- zwiększenie zainteresowania studentów uczestnictwem w wykładach,

- rozwijanie myślenia projektowego, kreatywności, refleksyjności, a w konsekwencji odpowiedzialności za proces uczenia się,

- uruchomienie procesów grupowych umożliwiających rozwijanie kompetencji społecznych.

\section{Interaktywny wykład problemowy}

Czy współczesny wykładowca przestaje być wykładowcą w klasycznym rozumieniu? W opinii badanych tak właśnie jest. Zmianie powinien ulec sposób prezentacji treści kształcenia oraz rola wykładowcy. Jedną z propozycji jest prowadzenie interaktyw- 
nego wykładu problemowego, w trakcie którego wykładowca wraz ze studentami zmierza do rozwiązania problemu będącego tematem wykładu. Nauczyciel akademicki, wchodząc w interakcje ze studentami, odwołuje się do ich doświadczeń i wiedzy uprzedniej.

Ustalono, że każdy wykład problemowy powinien:

- zaczynać się od pytania otwarcia, na które w trakcie wykładu udzielona zostanie odpowiedź,

- następnie zadając uprzednio przemyślane i odpowiednio sformułowane pytania szczegółowe, wykładowca wraz ze studentami dąży do rozwiązania problemu,

- w przypadku braku informacji zwrotnej, pochodzącej od studentów, nauczyciel uzupełnia informacje, następnie zadaje kolejne pytanie,

- w celu bardziej zrozumiałego przedstawienia informacji można posłużyć się wizualizacją.

Wykładowca, odgrywając rolę przewodnika, mentora, przeprowadza studentów od uświadomionej niewiedzy do rozwiązania problemu, inspirując i prowokując do myślenia, zastanawiania się nad kolejnym etapem rozwiązania.

Do przygotowania wykładu problemowego można posłużyć się metodą case study, odnosząc się do rzeczywistych sytuacji i zdarzeń. Najważniejsze jest aktywizowanie studentów, ciągłe stymulowanie ich ciekawości poznawczej, zmuszanie do refleksji, wysiłku intelektualnego.

Zdaniem wykładowców zastosowanie elementów aktywizujących może spowodować wywołanie większego skupienia uwagi i zaangażowania studentów w przebieg wykładu. Jednym z zaproponowanych rozwiązań jest przeprowadzenie $\mathrm{w}$ trakcie zajęć quizu sprawdzającego poziom zrozumienia poznawanych treści. Sytuację kontroli można zaaranżować w trakcie lub po zakończeniu wykładu. Osoby, które osiągną najlepszy wynik, mogą zostać gratyfikowane zgodnie $\mathrm{z}$ ustalonymi wspólnie zasadami. Przykładem prostej aplikacji chmurowej, za pomocą której można przygotować sprawdzian, jest Kahoot.com. Takie rozwiązanie metodyczne może zwiększyć motywację studentów do aktywnego słuchania oraz zwiększyć 
frekwencję na wykładach. Dzięki zastosowaniu quizu można podsumować najistotniejsze wątki omawianych treści kształcenia, ujmując je w określoną strukturę. Sprawdzany jest również sposób i zakres rozumienia zagadnień, które stanowiły treść wykładu. Zaletą tego rozwiązania jest automatyczne uzyskanie informacji zwrotnej na temat postępów studentów. Analiza wyników quizu pozwala na dokładne prześledzenie, które treści kształcenia zostały opanowane wystraczająco, a które $\mathrm{w}$ stopniu niezadowalającym. Wadą tego rozwiązania jest konieczność dostępu do internetu w trakcie zajęć. Ze względu na niewielką, ale jednak istniejącą możliwość wystąpienia problemów technicznych, nie zaleca się stosowania aplikacji do oceny wiedzy studentów. Innym sposobem zaproponowanym przez badanych, mającym zachęcić uczących się do aktywnego uczestnictwa $\mathrm{w}$ wykładzie, jest robienie przez nich notatek graficznych (np. w postaci mapy myśli), ilustrujących treść wykładu.

\section{„Kiedyś wystarczyła kreda i tablica, i wykład był zrozumiały"}

Przy omawianiu sposobu prowadzenia wykładu zwrócono uwagę na jego niską efektywność mimo stosowania wizualizacji, w celu ułatwienia zrozumienia prezentowanych treści. Na wstępie analizie poddano przebieg wykładu prowadzonego klasycznie, szczególnie zwracając uwagę na rolę obrazów przedstawianych na tradycyjnej tablicy czy też przy pomocy przygotowanych plansz. Analiza takiego przypadku doprowadziła do następujących konkluzji:

- wykładowca najczęściej posługiwał się słowem mówionym, ilustracji używał wyłącznie do przedstawienia najistotniejszych informacji, które zapisywane w odpowiedniej kolejności tworzyły strukturę omawianych treści (idea), przedstawione rysunki były w trakcie wykładu omawiane,

- ilustracji podlegały treści, które miały szczególne znaczenie dla zrozumienia istoty rzeczy, 
- plansze zawierały ilustracje omawiane przez wykładowcę w trakcie wykładu.

Podsumowując, wizualizacja uzupełniała treść wygłaszanego wykładu, ułatwiając zrozumienie jego treści. Obraz pojawiał się w związku z wypowiadanym komunikatem werbalnym.

Kolejnym działaniem podjętym przez wykładowców była analiza prezentacji przygotowywanych do wykładu przy pomocy programów prezentacyjnych (np. PowerPoint). W trakcie analizy zwrócono uwage na następujące błędy metodyczne:

- na prezentacjach często znajduje się zbyt duża ilość tekstu sytuacja ta utrudnia studentom śledzenie toku wykładu, wyodrębnienie jego głównych wątków, zrozumienie istoty rzeczy. Ich uwaga skupia się na przepisywaniu treści z wyświetlonych obrazów z przekonaniem, że wykładowca może za chwilę zmienić slajd i nie zdążą zrobić notatki,

- jednoczesne omawianie wyświetlanej na ekranie obszernej informacji tekstowej - studenci muszą dokonywać wyboru: słuchać czy przepisywać, sytuacja ta jest niekomfortowa i zaburza percepcję treści,

- szczególnie złą praktyką jest czytanie treści wykładów ze slajdów,

- studenci wyłączają się z aktywnego słuchania, gdy wiedzą, że prezentacja w rozbudowanej wersji zostanie im po wykładzie przesłana,

- źle przygotowana prezentacja - prezentowane obrazy są niewidoczne z dużej odległości na sali wykładowej - studenci nie są w stanie właściwie zinterpretować treści, zbyt wiele kolorów i krojów czcionek utrudnia hierarchizację treści, nieprzestrzeganie zasady kontrastu, rozmycie kolorów powoduje nieczytelność obrazu.

Wynikiem analizy było określenie celu i zasad przygotowywania oraz udostępniania prezentacji do wykładu.

- treść prezentacji powinna, tak jak w przypadku tradycyjnej tablicy, zawierać wyłącznie ilustracje umożliwiające lepsze zrozumienie treści wykładu (schematy, tabele, wykresy, ry- 
sunki, zestawienia), przygotowane wizualizacje powinny pojawiać się chronologicznie, w korelacji z omawianymi treściami. Slajd nie powinien zastępować wykładowcy i tego co ma do powiedzenia. Należy pamiętać, że na tradycyjnej tablicy wykładowca nigdy nie zapisywał całej swojej wypowiedzi. Obowiązuje zasada minimalizacji ilości tekstu;

- przygotowanie prezentacji wymaga sprawdzenia jej czytelności z każdego miejsca sali, w której odbywa się wykład. Mało widoczne opisy lepiej zastąpić symbolami, omawiając wcześniej legendę;

- kolory i rodzaj czcionki oraz jej atrybuty stanowią wskazówkę dla studentów dotyczącą struktury przedstawianej informacji. Zaleca się stosowanie jednego rodzaju czcionki (najlepiej bezszeryfowej). Strukturę informacji najlepiej budować posługując się jej atrybutami (wielkość, pogrubienie, pochylenie, podkreślenie). Kolory niosą znaczenie, dlatego kolorem wyróżnia się informacje najistotniejsze lub zawierające ostrzeżenie;

- zasada kontrastu - w przypadku projektowania prezentacji, powinna stanowić podstawową wytyczną dla twórcy wizualizacji.

W trakcie analizy zwrócono uwagę jeszcze na jedną niezwykle ważną kwestię. Pokazując „przepełnione tekstem” informacje, wykładowcy narażają się na pytania związane z udostępnieniem przygotowanego materiału wizualnego. Nie byłoby $w$ tej sytuacji nic nieprawidłowego, pod warunkiem, że studenci będą traktowali prezentację jako pewne kompendium stanowiące podstawę do dalszego studiowania. Niestety zdarza się, że traktują oni otrzymany, wypełniony tekstem materiał jako główne źródło wiedzy przygotowujące ich do egzaminu. Należy zauważyć, że stwierdzenie „przynajmniej niech się tego nauczą" nie tylko ogranicza wysiłek intelektualny studentów związany z pogłębioną analizą informacji i poszukiwaniem rozwiązań zagadnień związanych z poznawaną dziedziną na podstawie wielu źródeł, ale również w pewnym zakresie ogranicza ich aktywność poznawczą, skrajnie może doprowadzić do kuriozalnej sytuacji „nie dostałem materiałów od wykładowcy, więc się nie przygotowałem do egzaminu". 
Uznano, że rozwiązaniem tej sytuacji będzie stworzenie repozytorium prezentacji do wykładu, ilustrujących omawiane treści, które każdy student przed wykładem może wydrukować i w trakcie wykładu, aktywnie słuchając, uzupełniać o potrzebne informacje. Miejscem, w którym powstanie takie repozytorium może być uczelniana platforma e-learningowa. Prowadzone badania dowodzą, że tworzone $\mathrm{w}$ ten sposób notatki studenckie różnią się w zależności od wiedzy uprzedniej studentów.

Przedstawione rozwiązania wypracowane przez badanych nawiązują do badań opisanych $\mathrm{w}$ zakresie psychologii kształcenia ${ }^{8}$ i psychologii motywacji ${ }^{9}$. W ciągu najbliższego semestru zostaną wdrożone do procesu kształcenia poddane ewaluacji.

\section{Podsumowanie}

Współczesna dydaktyka akademicka zmienia się. Jej realizacja wymaga modyfikacji w zakresie form i metod kształcenia w kontekście współczesnych celów kształcenia. Receptą może okazać się zastosowanie nowoczesnych rozwiązań metodycznych, które sprzyjają zwiększeniu zaangażowania studentów w proces uczenia się, motywacji, współpracy i zdrowej rywalizacji. We współczesnym procesie kształcenia kluczowym jest rozwijanie myślenia, autorefleksji i samodoskonalenia. Bardzo istotne jest osiągnięcie przez studentów poziomu metauczenia się.

Niezbędna okazuje się modyfikacja współczesnej dydaktyki akademickiej. Kluczowe stało się odcięcie kadry wykładowców od własnych doświadczeń edukacyjnych, najczęściej nieadekwatnych do współczesności.

${ }^{8}$ G. Mietzel, Psychologia kształcenia, Gdańskie Wydawnictwo Psychologiczne, Gdańsk 2003.

${ }^{9}$ R.E. Franken, Psychologia motywacji, Gdańskie Wydawnictwo Psychologiczne, Gdańsk 2013. 


\section{Bibliografia}

Bloom B.S., Taxonomy of Educational Objectives Book 1: Cognitive Domain, 2nd edition. Addison Wesley Publishing Company, New York 1984.

Bruner J.S., Haste H., Making sense. The child's construction of the world, Methuen, New York 1987.

Franken R.E., Psychologia motywacji, Gdańskie Wydawnictwo Psychologiczne, Gdańsk 2013.

Friedrich R., Peterson M., Koster A., Blum S., The Rise of Generation C. Implications for the World of 2020, Booz \& Company, s. 2. http://www.itdl.org/journal/jan_ 05/article01.htm 2010 [dostęp: 15.07.2018].

Mietzel G., Psychologia kształcenia, GWP Gdańskie Wydawnictwo Psychologiczne, Gdańsk 2003.

Morańska D., Refleksyjne uczenie się w akademickiej edukacji zdalnej. https://repozy torium.ur.edu.pl/handle/item/2967, 2017 [dostęp: 15.07.2018].

Morbitzer J., O istocie medialności młodego pokolenia, „Neodidagmata”, nr 33/34, 2011-2012, s. 136-139.

Niemierko B., Ocenianie szkolne bez tajemnic, WSiP, Warszawa 2002.

Perkowska-Klejman A., Modele refleksyjnego uczenia się, http://terazniejszosc.dsw. edu.pl/fileadmin/user_upload/wydawnictwo/TCE/2013_61_5.pdf, 2013 [dostęp: 15.07.2018]. 